TITLE:

\title{
Factors in the Development of Trade Credit: Case Study of Provinces in China
}

$\operatorname{AUTHOR}(S):$

Yano, Go; Shiraishi, Maho

\section{CITATION:}

Yano, Go ... [et al]. Factors in the Development of Trade Credit: Case Study of Provinces in China. Emerging Markets Finance and Trade 2014, 50(s2): 114-134

ISSUE DATE:

2014-12-05

URL:

http://hdl.handle.net/2433/199592

\section{RIGHT:}

This is an Accepted Manuscript of an article published by Taylor \& Francis in Emerging Markets Finance and Trade on 2014, available online: http://www.tandfonline.com/10.2753/REE1540-496X5002S208:; 許諾条件により本文ファイルは 2016-06-05に公開,; この論文は出版社版でありません。引用の際には出版社版をご確認ご利用ください。; This is not the published version. Please cite only the published version. 


\title{
Factors in the Development of Trade Credit: Case Study of Provinces in China
}

\begin{abstract}
Using Chinese province-level panel data for 2001-2009, we investigate significant factors for the development of financial intermediation via trade credit in developing economies. First, we confirm that a competitive market environment, a well-functioning legal system and greater bank loans for non-state-sector firms promote the development of trade credit in China. Conversely, corruption hinders its development. Second, proper functioning of the legal system and bank lending to non-state-sector firms are highly likely to be the cause of the complex relationships between these determinants. Finally, an increase in the number of lawyers effectively improves the quality and function of the legal system, which in turn alleviates the harmful influence of corruption on trade credit development.
\end{abstract}

JEL classification numbers: G32; O16; O53; P34.

Keywords: trade credit development in China; competitive market; well-functioning legal system; corruption; bank loans for non-state-sector firms. 


\section{Introduction}

Taking China as a case study, we investigate significant determinants for the development of financial intermediation through trade credit in developing economies. ${ }^{1}$ In general, developing economies including China do not have a well-developed formal financial system such as banks and a capital market. In this environment, trade credit is an important candidate for effective alternative financing. Demirgüc-Kunt and Maksimovic (2001) argue that firms are more likely to rely on trade credit in economies with inferior legal systems. Almost all developing economies have less efficient legal institutions. Özlü and Yalçın (2012) find that financially constrained firms with limited access to bank finance tend to substitute trade credit in Turkey, which has a more developed economy than China.

Previous studies provide a background for this work. Many have investigated the supplier motivation for offering trade credit. On the one hand, some argue that a competitive market environment promotes the development of trade credit. Fabbri and Klapper (2008) and Van Horen (2004) show empirically that firms with weak market power relative to their customers generally offer more trade credit. Since the weak market power of supplier firms compared to their customers mainly stems from the competitive market for their products, these findings can be interpreted as supporting the concept that a competitive market environment can promote the development of financial intermediation through trade credit. Fisman and Raturi (2004) present a theoretical overview of market competition and trade credit provision. They state that competition among suppliers encourages customers to build a relationship with a supplier and establish creditworthiness

\footnotetext{
${ }^{1}$ We call the development of financial intermediation through trade credit "development of trade credit" or "trade credit development" hereafter.
} 
to obtain trade credit. Their theoretical expectation is supported by empirical evidence from African data. Taking Indonesian firms as a case study and using firm-level micro-data, Hyndman and Serio (2010) report an interesting finding: an inverse U-shaped relationship exists between market competition and trade credit supply by vendors. ${ }^{2}$

On the other hand, securing of property rights by a legal system can positively affect the development of trade credit. In studying the relative importance of the courts and their relationship in contract enforcement in the context of Russia, Ukraine and Eastern European countries, Johnson et al. (2002) confirm that legal protection of property rights by well-functioning courts encourages entrepreneurs to offer trade credit.

However, to the best of our knowledge, there has been no comprehensive empirical analysis of the determinants of trade credit development, particularly in the context of developing economies. Previous studies focused on single determinants of trade credit development and did not investigate the complex relations between determinants. Therefore, we investigate the effective determinants of trade credit development among candidate factors in the context of developing economies. Chinese province-level data are used. The differences in trade credit development between provinces enable us to tackle this issue effectively.

The viewpoint of trade credit development in the context of the Chinese economy also provides important suggestions for our tests.

Pointing out that although it does not have a well-developed legal or financial system,

\footnotetext{
2 Aktas et al. (2012) present an interesting explanation and empirical evidence of the motivation for firms to receive trade credit rather than offer it. They argue that firm mangers use trade credit finance to convey valuable information to external investors, such as the quality of the firm's investments.
} 
China has one of the fastest-growing economies, Allen et al. (2005) argue that China may be an important counter-example to the focus of the legal and financial literature on formal systems. They suggest that alternative financing channels, rather than formal external finance, support the fastest-growing Chinese firms, namely private firms. In response to their argument, several studies have investigated whether alternative financing channels really work as a substitute for formal financial systems in supporting the growth of firms and the economy in China (Cheng and Degryse, 2007; Ge and Qiu, 2007; Ayyagari et al., 2010; Cull et al., 2009; Du et al., 2012). Although no consensus on this issue has been reached, alternative financing channels are likely to contribute to the fast economic growth of China, at least to some extent.

As stated above, one possible alternative financing channel is trade credit. Among the studies mentioned, Cull et al. (2009) and Ge and Qiu (2007) explicitly explore trade credit in China. ${ }^{3}$ Statistical findings by Fabbri and Klapper (2008) are derived from firm-level micro-data for Chinese firms.

Fisman and Raturi (2004) state that previous research has often treated trade credit access as a proxy for inter-firm trust (Johnson et al., 2002; Fafchamps, 2004), which they adopt in their own work. Therefore, our investigation of the determinants of trade credit development in China can be also interpreted as a study of factors that lead to trust between Chinese firms. The development of inter-firm trust should contribute to economic growth in

${ }^{3}$ Using a World Bank data set of Chinese firms, Du et al. (2012) compare the relative importance of bank loans and trade credit in promoting firm performance. While their findings favor bank loans over trade credit, there are crucial problems in their empirical analysis, including an invalid instrumental variable for trade credit, inadequate control of the market structure (monopolistic or competitive) and differing production technology between industries, and the influence of outliers. 


\section{China.}

\section{(Figures 1 and 2)}

Fig. 1 shows a positive correlation between the development of trade credit and the provincial economy. ${ }^{4}$ This positive correlation implies that economically more developed coastal provinces have more developed trade credit than economically less developed interior provinces. 5

Furthermore, interior provinces not only had less developed trade credit in the early 2000s, but have failed to develop trade credit since then, while coastal provinces had more developed trade credit in the early 2000s and have further developed trade credit since then. As a result, the disparity in trade credit development between interior and coastal provinces has increased (Fig. 2). This puts in question the sustainability of recent economic development in the interior provinces. Therefore, it is important to investigate how to develop trade credit in China to guide policy-making for effective financing channels, particularly in the interior provinces.

${ }^{4}$ Fig. 1 provides observation data for 2008. Similar positive correlations exist for each year during the period 2001-2009, but are not reported for the sake of brevity. Furthermore, while we measure the development of trade credit in a province as accounts receivable/gross assets, we can obtain the same positive correlation between the development of trade credit and the provincial economy even when using accounts payable/gross assets. This is because accounts receivable and payable are largely balanced in a province. For firm-level behavior, Fabbri and Klapper (2008) also find that firms tend to match contract terms for accounts receivable and payable in China, which likely results in balanced receivables and payables.

5 Coastal areas here comprise the following provinces: Beijing, Tianjin, Hebei, Liaoning, Shanghai, Jiangsu, Zhejiang, Shandong, Fujian, and Guangdong. The interior areas studied comprise the other provinces. 
Section 2 explains the conceptual framework and introduces candidate determinants of trade credit development in China and the complex relations among them. Section 3 specifies the empirical models used and explains the estimation strategy. Section 4 presents the data used for our econometric analysis. Section 5 describes and discusses the estimation results. Conclusions are presented in Section 6.

\section{Conceptual framework}

In this section we construct the basic framework for our study by introducing several candidate determinants of trade credit development in China and describing the complex relations among them.

\subsection{Candidate determinants of trade credit development in China}

We consider the following four candidate determinants of trade credit development in China: a competitive market environment, a well-functioning legal system, less corruption, and financial factors affecting demand and supply for trade credit finance. ${ }^{6}$

${ }^{6}$ Giannetti et al. (2011) find that suppliers of differentiated products and services offer greater trade credit than suppliers of standardized goods. This is likely because suppliers of differentiated products and services are hard to replace since they provide unique or highly customized inputs and differentiated products and services are difficult to divert for unintended purposes. This leads to strong relationships between suppliers of differentiated goods and services and their customers and shields such suppliers against buyer opportunism (Burkart and Ellingsen, 2004). This finding suggests that industrial relationships between firms and the nature of goods traded is a determinant for trade credit development. Unfortunately, however, data accurately capturing these relationships at 


\section{(1) Competitive market environment}

As shown by Van Horen (2004), Fisman and Raturi (2004), and Fabbri and Klapper (2008), a competitive market environment is a prospective determinant of trade credit development. The reason for choosing this candidate determinant has been provided in Section 1. A variant of market competitiveness is the presence of small and medium-sized enterprises (SMEs). First, a greater SME presence directly implies a more competitive market environment. Second, SMEs - which are likely to suffer more from credit constraints because of weaker banking relationships - tend to demand trade credit finance (Petersen and Rajan, 1997; Nilsen, 2002; Fisman and Love, 2003). ${ }^{7}$

\section{(2) A well-functioning legal system}

As Johnson et al. (2002) find in the context of Russia, Ukraine and Eastern European countries, legal protection of property rights can encourage trade credit via more reliable contract enforcement. More reliable contract enforcement enables more trade credit to be granted and received. However, Demirgüc-Kunt and Maksimovic (2001) find that firms tend to rely on trade credit in economies with inferior legal systems. This implies the possibility that an ill-functioning legal system compels firms to use trade credit as mutually beneficial financial intermediation. In this case, the legal system is a negative factor for the development of trade credit.

provincial level in China are unavailable. Therefore, this candidate determinant could not be investigated in the present study.

7 The attachment of importance to market structure, specifically the presence of SMEs, is based on a helpful comment by an anonymous reviewer. 


\section{(3) Less corruption}

Corruption as a negative factor is a candidate determinant of trade credit development. Here we assume that corruption essentially involve insecure property rights due to expropriation by the government and weak institutions for contract enforcement (Acemoglu and Johnson, 2005; Cull and Xu, 2005). Acemoglu and Johnson (2005) and Cull and Xu (2005) separate insecure property rights into failed protection of citizens against expropriation by the government and unreliable contract enforcement. However, in the reality of the Chinese economy, these two types of insecure property rights are closely related. Our field survey in China reveals anecdotal observations that grabbing of firms by the government causes unreliable contract enforcement and thus reduces the motivation for firms to execute contracts for payment. Firms attach greater importance to maintaining good relations with the government to alleviate such grabbing or obtain government protection in the political field than to establishing trust with their business partners by executing contracts in the market. ${ }^{8}$ This in turn also discourages their business partner firms from executing contracts. Unreliable contract execution then hinders trade credit development.

\section{(4) Financial factors: demand and supply for trade credit finance}

Financial factors are also likely to be important for trade credit development. These

\footnotetext{
${ }^{8}$ Cai et al. (2011) empirically investigate corruption in China using firm data for entertainment and travel costs. Their theoretical framework and statistical evidence suggest a type of tradeoff between investments by firms into relational capital with their business partners in the economic field and into relational capital with the government in the political field.
} 
factors can affect trade credit development through both demand for and supply of trade credit finance. As stated in the next section, demand for trade credit finance mainly comes from non-state-sector firms in China. In addition, the higher value of accounts receivable/gross assets for non-state-sector compared to state-sector firms in the China Economic Census Yearbooks 2004 and 2008, for example, indicates that the main suppliers of trade credit are also non-state-sector firms. Therefore, we pay particular attention to demand for and supply of trade credit in non-state-sector firms.

On the demand side, firms with less access to substitutive external funds, typically bank loans, may be more dependent on receiving trade credit for their finance. ${ }^{9}$ Biais and Gollier (1997) argue that firms receive more trade credit when they receive less in bank loans. Therefore, more bank loans for non-state-sector firms can lead to less demand for trade credit finance. ${ }^{10}$ Furthermore, a higher share of non-state-owned commercial banks in total bank lending is expected to increase bank loans for non-state-sector firms, since the primary function of state banks is to channel savings to state-sector firms in China (Guariglia and Poncet, 2008; Boyreau-Debray, 2003). Therefore, a higher share of non-state-owned commercial banks in total bank lending could also decrease demand for trade credit finance by increasing bank loans for non-state-sector firms. Thus, when focusing on the demand side for trade credit finance, bank loans for non-state-sector firms and the share of non-state-owned commercial banks in total bank lending are direct and indirect negative factors, respectively. However, we should also take into account other

${ }^{9}$ Our consideration of demand-side factors for trade credit is based on a useful comment by an anonymous reviewer.

10 This arises partly from the more expensive financing costs for trade credit than bank loans (Brandt and Li, 2003). 
effects, namely, supply-side factors.

On the supply side, more bank loans for non-state-sector firms and a higher share of non-state-owned commercial banks in total bank lending can allow non-state-sector firms, the main suppliers of trade credit, to offer more trade credit to their customers. In other words, it could be that these two factors facilitate credit creation among firms using trade credit. Considering the biased financial allocation through bank lending to state-sector over non-state-sector firms in China, the influence on trade credit supply of bank loans for non-state-sector firms cannot be ignored (Guariglia et al., 2011; Ding et al., 2012). Thus, when focusing on the supply side for trade credit finance, these are positive factors. It depends on whether the demand effect or the supply effects are dominant as to whether these financial factors work positively or negatively for trade credit development in China. This should be investigated empirically.

\subsection{Complex relations between the determinants}

The determinants mentioned above are not independent but have complex relations with each other. An example is the causality between two determinants whereby a well-functioning legal system could directly alleviate corruption, which subsequently results in trade credit development. More bank loans for non-state-sector firms and a higher share of non-state-owned commercial banks in total bank lending might also mitigate government corruption. The mechanism might be that more bank loans for non-state-sector firms (or, equivalently, fewer bank loans for state-sector firms) that are possible government expropriation targets might allow them to avoid corruption, namely being grabbed by the government.

Corruption could also affect other determinants. It is likely to discourage prospective firms from entering the market for fear that the government will grab them. This definitely 
leads to a less competitive market environment. On the contrary, a well-functioning legal system is likely to encourage prospective firms to enter the market via secure property rights and contract enforcement. This leads to a competitive market environment.

Furthermore, serious corruption could harm the functioning of the legal system through political pressure from the government. In addition, corruption could be associated with greater financial support of state-sector firms through bank lending.

To analyze these complex relations, we consider first-stage estimation results in an econometric analysis using system GMM estimation with "collapsed" instrumental variables. This will give us an insight into which determinants are primary factors in trade credit development, which should be priority targets for policy makers.

\section{Empirical models and estimation strategy}

This section explains the empirical models and estimation strategy used to analyze the significant determinants of trade credit development in China. For this purpose, we use the following empirical model:

Trade credit development $_{\text {it }}=\alpha+\alpha_{\mathrm{t}}+\beta_{1}$ competitive market environment ${ }_{\mathrm{it}-1}$

$$
\begin{aligned}
& +\beta_{2} \text { legal system }_{\mathrm{it}-1}+\beta_{3} \text { corruption }_{\mathrm{it}-1} \\
& +\beta_{4} \text { financial factors }_{\mathrm{it}-1}+\varepsilon_{\mathrm{it}}
\end{aligned}
$$

where $\mathrm{i}$ and $\mathrm{t}$ denote the province and time (year), respectively, and

$$
\varepsilon_{\mathrm{it}}=\mu_{\mathrm{i}}+\mathrm{e}_{\mathrm{it}}
$$

The disturbance term $\varepsilon$ it has two components: the province-specific fixed effect $\mu_{\mathrm{i}}$ and the 
pure error term (idiosyncratic shocks) $\mathrm{e}_{\mathrm{it} .}{ }^{11}$ The error term $\mathrm{e}_{\mathrm{it}}$ is taken to be independently distributed over $\mathrm{i}$ and $\mathrm{t}$ with zero mean. The province-specific fixed effect $\mu_{\mathrm{i}}$ is expected to control unobservable province-specific and time-invariant factors. $\alpha_{\mathrm{t}}$ is a year-specific term. Thus, $\beta_{1}, \beta_{2}, \beta_{3}$ and $\beta_{4}$ are the coefficients to be estimated.

We set a one-period time lag between the dependent variable (trade credit development $_{\mathrm{t}}$ ) and important independent variables (competitive market environment ${ }_{\mathrm{t}-1}$, legal system ${ }_{\mathrm{t}-1}$, corruption $\mathrm{t}_{\mathrm{t}-1}$, and financial factors $\mathrm{t}_{\mathrm{t}-1}$ ) to avoid reverse causality between the dependent and independent variables as much as possible. Variables in bold font represent variable vectors.

We use the system GMM estimation technique developed by Blundell and Bond (1998) in panel estimation to cope with the remaining endogeneity problem of independent variables. ${ }^{12,13,14}$ The system GMM estimator is designed to address the endogeneity of independent variables in panel estimation and the weak instrument problem in the first-differenced GMM proposed by Arellano and Bond (1991). It combines regression in differences with regression in levels, where the instruments for the former are generally the

11 In system GMM estimation, it is difficult to assume random effects for the firm-specific term $\mu_{\mathrm{i}}$ because $\mu_{\mathrm{i}}$ is structurally correlated with lagged dependent variable as an independent variable in the dynamic panel model for which first-differenced and system GMM estimations were originally proposed.

12 Typically, the remaining endogeneity problem of independent variables is caused by reverse causality from dependent to independent variables and omitting an independent variable into the error term $\mathrm{e}_{\mathrm{it}}$.

13 See Roodman (2008) for the system GMM estimation.

${ }^{14}$ We use two-step instead of one-step GMM since the former is asymptotically more efficient. Thus, we apply the Windmeijer (2005) finite-sample correction to the two-step covariance matrix to settle the potentially downward-biased two-step standard errors. 
lagged levels of endogenous or predetermined variables and the instruments for the latter are the lagged differences of those variables.

Among the independent variables introduced above, province and year dummies measuring province- and year-specific effects, respectively, can be assumed to be exogenous. Endogeneity is suspected for the other independent variables. A one-period lag is taken for these variables. Strictly speaking, therefore, they are not endogenous but are predetermined variables in that they can be correlated with $\mathrm{e}_{\mathrm{it}-1}$ and e before period $\mathrm{t}-1$ and cannot be correlated with $\mathrm{e}_{\mathrm{it}}$ and e after period t. Since realizations of the predetermined variables occur before that of the current error term $\mathrm{e}_{\mathrm{it}}$, they cannot be correlated.

Thus, in system GMM, estimation of first-differenced and level equations for (1) is conducted using adequate instrument variables for each equation. The first-differenced equation for (1) removes and controls unobservable province-specific and time-invariant factors, $\mu_{\mathrm{i}}$. Thus, for the first-differenced equation, two-period lagged levels of the

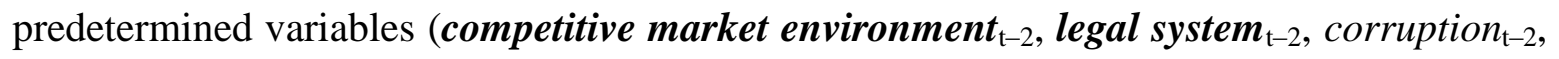
and financial factors $_{\mathrm{t}-2}$ ) are used as instrumental variables in addition to first-differenced year dummies as exogenous variables. The coefficients for province dummies are estimated in level equation (1). Thus, for estimation of level equation (1), one-period lagged differences for the predetermined variables (Acompetitive market environment ${ }_{\mathrm{t}-1}$, Alegal system $_{\mathrm{t}-1}$, Acorruption $_{\mathrm{t}-1}$, and $\Delta$ financial factors $_{\mathrm{t}-1}$ ) are used as instrumental variables in addition to province and year dummies as exogenous variables. Here, lagged differences for the predetermined variables are defined as $\Delta X_{\mathrm{it}-1}=X_{\mathrm{it}-1}-X_{\mathrm{it}-2}$.

To avoid overfitting of large instruments to endogenous variables, we limit instrument variables to two-period lagged levels and one-period lagged differences of the predetermined variables besides exogenous variables, and use these instruments in collapsed form (Roodman, 2008, 2009). Because the data are provincial panel data and the 
number of individual units (provinces in this case) is relatively small, we should pay particular attention to the overfitting problem in using large instruments. Furthermore, these limited instruments enable us to easily check the first-stage estimation results. This is quite helpful for disentangling the complex relations between determinants of trade credit development in China.

The validity of the instruments introduced above depends on the two following assumptions. The first is that the instruments are exogenous. More precisely, the instruments used are not correlated with current error terms $\left(\Delta \mathrm{e}_{i t}=\mathrm{e}_{i t}-\mathrm{e}_{\mathrm{it}-1}\right)$ for difference regression and are not correlated with $\varepsilon$ it $=\mu_{\mathrm{i}}+\mathrm{e}_{\mathrm{it}}$ for level regression. The second is that the pure error term $\mathrm{e}_{\mathrm{it}}$ is not serially correlated. For these assumptions, two tests are proposed to assess the validity of the instruments. The first, for instrument exogeneity, is the Sargan or Hansen test of overidentifying restrictions, which tests the overall validity of an instrument by checking the validity of moment conditions in the sample used. ${ }^{15}$ The second, for serial correlation of $\mathrm{e}_{\mathrm{i}}$, is the autoregressive test proposed by Arellano and Bond (1991). By construction, the error term in difference regression is allowed to be first-order serially correlated, whereas second-order serial correlation of the error term violates the instrument validity. Thus, checking the second-order serial correlation of the differenced error term, $\operatorname{AR}(2)$, works as a test for serial correlation of $\mathrm{e}_{\mathrm{it}}$.

To measure trade credit development, the dependent variable, we use accounts receivable for non-state-sector firms/gross assets. Trade credit has an even more important role in the corporate finance of non-state-sector compared to state-sector firms (Ge and Qiu, 2007), which is why we use trade credit development for non-state-sector firms as the

15 We use the Hansen test as the overidentifying restriction test because the Sargan test statistic is not robust to heteroscedasticity, while the Hansen test statistic, which is the minimized value of the two-step GMM criterion function, is robust. 
dependent variable of our empirical model.

We now turn to the independent variables.

Competitive market environment represents variables for measuring how competitive the economy of a province is for each year. The variables are (number of firms/province industrial gross output $)_{-1}$ and producer price indices for manufactured goods $s_{-1}$. More precisely, number of firms refers to industrial firms. Note that a higher second variable represents a more monopolistic and thus a less competitive market environment. The presence of SMEs, a variant of market competitiveness, is measured by presence of SMEs in gross output -1 for each province.

Legal system represents variables for measuring how well the legal system works. The variables are (patent applications accepted/province GRP $)_{-1}$, (number of commercial cases received by the court/province population) $)_{-1}$ and (number of lawyers/province

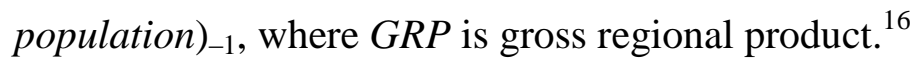

Corruption measures how serious the corruption situation is in a province for each year. The variable is (number of registered corruption cases/province population) $)_{-1}$.

Finally, as financial factors affecting trade credit development, we consider two

16 Here, we normalize patent applications accepted and the number of commercial cases received by the court (or number of lawyers) by province GRP and population, respectively. To check the robustness of our estimates, we also normalized patent applications accepted and the number of commercial cases received by the court (or number of lawyers) by population and GRP, instead of GRP and population, respectively. Even when we exchanged the normalizing denominators, we obtained largely unchanged estimation results, but these are not reported for the sake of brevity. When we replaced (number of registered corruption cases/province population) $)_{-1}$ with (number of registered corruption cases/province $G R P)_{-1}$, the results were similar to the case for patent applications and commercial cases (or lawyers). 
variables measuring bank loans for non-state-sector firms and the share of non-state-owned commercial banks in total bank lending. The first is measured by (bank loans for non-state-sector firms/gross assets) $)_{-1}$. The second, namely, share of non-state-owned commercial banks in total bank lending ${ }_{-1}$, is a measure for itself.

\section{Data}

We use province-level aggregated data for 2001-2009 as our provincial panel data.

The dependent variable, trade credit development $=$ accounts receivable for non-state-sector firms/gross assets, comes from the China Industry Economy Statistical Yearbook for various years and the China Economic Census Yearbook 2004.

Data for the competitive market environment variables, (number of firms/province industrial gross output $)_{-1}$, (number of firms/province population $)_{-1}$, and producer price indices for manufactured goods $s_{-1}$, were obtained data from the China Statistical Yearbook (CSY), as were data for province population. Data on presence of SMEs in gross output -1 are from Yearbook of China Small and Medium Enterprises for various years.

We use three legal system variables. Among them, data for (patent applications accepted/province $G R P)_{-1}$ are from CSY. In constructing (number of commercial cases received by the court/province population) $)_{-1}$ and (number of lawyers/province population $)_{-1}$, the number of commercial cases received by the court and the number of lawyers were obtained from the Law Yearbook of China, China Procuratorial Yearbook, China Judicial Administration Yearbook (zhongguo sifa xingzheng nianjian) and Chinese Yearbook of Lawyers for various years, as well as by direct data collection from the Ministry of Justice of China.

In constructing the corruption variable (number of registered corruption cases/province population $)_{-1}$, the number of registered corruption cases was obtained from 
the China Procuratorial Yearbook.

Data on (bank loans for non-state-sector firms/gross assets) $)_{-1}$ are from the China Industry Economy Statistical Yearbook for various years and the China Economic Census Yearbook 2004. Finally, share of non-state-owned commercial banks in total bank lending $_{-1}$ is obtained from the Almanac of China's Finance and Banking for various years and directly from the People's Bank of China.

Table 1 presents the descriptive statistics.

\section{(Table 1)}

\section{Estimation results}

Table 2 presents the final system GMM estimation results.

\section{(Table 2)}

For all specifications, the Hansen test of overidentifying restrictions shows p-values that cannot reject the null hypothesis that instruments used for the estimation are exogenous. Furthermore, results for AR(2) also cannot detect serial correlation of $\mathrm{e}_{i t}$ at the usual critical value for any specification. These results confirm the validity of the instruments used.

For all specifications, the competitive market environment variables (number of firms/province industrial gross output $)_{-1}$, producer price indices for manufactured goods $s_{-1}$ and presence of SMEs in gross output -1 have significantly positive, negative, and positive coefficients, respectively. These results confirm, as suggested by previous studies, that a competitive market environment promotes the development of trade credit in China.

The legal system variables, namely (patent applications accepted/province GRP) , $_{1}$ (number of commercial cases received by the court/province population $)_{-1}$ and (number of lawyers/province population $)_{-1}$, also have significantly positive coefficients. As found by Johnson et al. (2002) for European transition economies, a well-functioning legal system is 
also very likely to encourage the development of trade credit in China. This finding seems to be inconsistent with results observed by Demirgüc-Kunt and Maksimovic (2001) that firms are more likely to rely on trade credit in economies with inferior legal systems. Taken together, the findings of Demirgüc-Kunt and Maksimovic and our results imply that, differing from formal financial institutions such as banks, trade credit can act as an alternative financial source even under an inferior legal system in developing economies to some extent, whereas improving the quality of the legal system is important for further development of trade credit.

The variable (number of registered corruption cases/province population $)_{-1}$, which measures the corruption in province $\mathrm{i}$ for year $\mathrm{t}-1$, has a significantly negative influence on trade credit development. As expected, corruption harms the development of trade credit.

One financial factor variable, (bank loans for non-state-sector firms/gross assets) ${ }_{-1}$, has significantly positive coefficients. The other financial factor variable, share of non-state-owned commercial banks in total bank lending ${ }_{-1}$, also has largely significant and positive coefficients. Greater bank loans for non-state-sector firms are thus a positive factor in the development of trade credit in China. This stems from the trade credit supply mechanism whereby more bank loans for non-state-sector firms facilitates credit creation among firms using trade credit under the biased financial allocation in which state-sector firms are favored for bank loans over non-state-sector firms in China.

Specification (1)-5 is a dynamic-type model with the one-period lagged dependent variable (accounts receivable for non-state-sector firms/gross assets) it-1 $_{\mathrm{i}-1}$ as andependent variable. The estimated coefficient is significantly negative, and we can obtain largely similar results regarding the other independent variables for static specifications. This confirms the robustness of our estimation results for empirical model (1).

Next, we try to disentangle the relations between these determinants of trade credit 
development in China.

As explained above, because of these limited instruments, we can easily check the first-stage results for system GMM estimation. This check helps us to disentangle the complex causal relations between the determinants of trade credit development in China. The results are shown in Tables 3, 4, 5, 6, 7 and 8 .

\section{(Tables 3 and 4)}

First, the levels and differences for competitive market environment variables in Tables 3 and 4 are affected by two-period lagged levels and one-period lagged differences for the legal system and corruption variables, respectively, in addition to those for themselves. The levels and differences for the legal-system variable have a positive effect and those for the corruption variable have a negative effect on competitive market environment variables. This confirms that a well-functioning legal system encourages prospective firms to enter the market, possibly via secure property rights and contract enforcement, which leads to a competitive market environment. On the contrary, corruption discourages prospective firms from entering the market for fear of government exploitation, which leads to a less competitive market environment.

\section{(Tables 5, 6, 7 and 8)}

We skip Tables 5 and 6 and look at the results for first-stage regression with corruption variables as the dependent variables in Tables 7 and 8 . The corruption variables are negatively affected by legal system variables and the financial factor variables representing bank loans to non-state-sector firms, in addition to themselves. Thus, we can confirm several points. First, we note the bridged causality starting from the legal system leading to corruption as an intermediary and eventually resulting in market competitiveness. Second, the corruption-promoting effect of financial support of state-sector firms (less financial support of non-state-sector firms) through bank lending confirms the mechanism 
mentioned above: government corruption is mitigated by restraining allocation of abundant financial resources to state-sector firms through bank lending in China.

Finally, legal system variables and the financial factor variables representing bank loans to non-state-sector firms in Tables 5-8 are explained only by lagged levels and differences for themselves. Differing from our expectation, there is no statistical evidence that corruption harms the functioning of the legal system through political pressure from the government or that corruption is associated with greater financial support of state-sector firms through bank lending. This suggests that the functioning of the legal system and bank lending to non-state-sector firms are highly likely to be the starting points for the complex causal relations. In addition, they have a direct positive influence on trade credit development in China, as we saw above. Therefore, these two factors should be policy targets with the highest priority for the development of trade credit. In other words, if policy makers want to develop financial intermediation via trade credit in China, improving the quality of the legal system and increasing bank lending to non-state-sector firms (reducing financial support of state-sector firms through bank lending) can be recommended.

We now return to the final estimation results in Table 2. Specifications (1)-6 and (1)-7 introduce two interaction terms: (number of commercial cases received by the court/province population $)_{-1} \times(\text { number of lawyers/province population })_{-1}$ and (number of

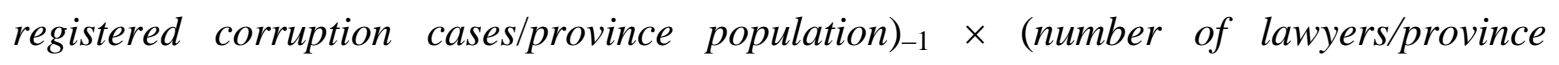
population $)_{-1}$. These are a measure of the effectiveness of an increase in the number of lawyers on trade credit development. The first interaction term was introduced to test whether an increase in the number of lawyers improves court quality and thus accelerates improvements in the legal system. An increase in the number of lawyers is one of the easiest policies to implement in improving the functioning of the legal system. The second 
interaction term was introduced to further investigate whether an increase in the number of lawyers and improved functioning of the legal system alleviate the harmful influence of corruption on trade credit development.

Although (1)-6 and (1)-7 are static and dynamic specifications, respectively, these two interaction terms have significantly positive coefficients in both specifications. This implies that improving the functioning of the legal system by increasing the number of lawyers can effectively contribute to the development of trade credit in China. First, the significantly positive coefficients for (number of commercial cases received by the court/province population $)_{-1} \times(\text { number of lawyers/province population })_{-1}$ suggest that an increase in the number of lawyers improves the quality and function of the legal system, which can promote trade credit development. Second, the significantly positive coefficients

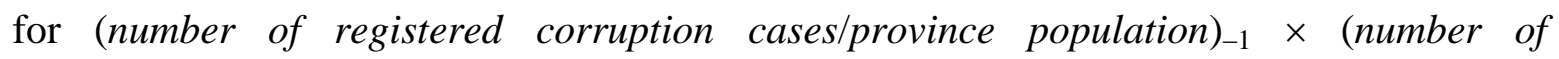
lawyers/province population $)_{-1}$ indicate that improving the functioning of the legal system by increasing the number of lawyers should alleviate the harmful influence of corruption on trade credit development. These results confirm that improving the functioning of the legal system is an effective policy target for trade credit development in China and that increasing the number of lawyers is a feasible and suitable way of achieving this policy target.

\section{Conclusions}

Using Chinese province-level aggregated panel data for 2001-2009, we investigated significant determinants for the development of financial intermediation via trade credit in a developing economy. The main findings are summarized as follows.

First, we confirmed that a competitive market environment, a well-functioning legal system and greater bank loans for non-state-sector firms promote the development of trade 
credit in China. In contrast to these factors, corruption hinders its development.

Second, these factors are not independent but have complex relations with each other. We can confirm these relations by checking the first-stage GMM estimation results, which is possible because of the limited instrument variables used in collapsed form. For example, a well-functioning legal system encourages prospective new firms to enter the market, possibly via secure property rights, which leads to a competitive market environment. Financial support of state-sector firms through bank lending has a corruption-promoting effect because granting of abundant financial resources to state-sector firms tends to promote government corruption in China via the stronger ability of these firms to endure corruption, namely being grabbed by the government.

Third, the first-stage GMM estimation results enable us to disentangle the complex relations between determinants. The statistical evidence suggests that functioning of the legal system and bank lending to non-state-sector firms are highly likely to be the starting points for these relations. A policy implication arising from this finding is that improving the quality of the legal system and increasing and reducing bank lending to non-state-sector and state-sector firms, respectively, should be given higher priorities for the development of trade credit in developing economies such as China.

Finally, an increase in the number of lawyers effectively improves the quality and function of the legal system, which in turn alleviates the harmful influence of corruption on trade credit development.

This study clarifies how trade credit develops in a developing economy using province-level aggregated panel data. However, many factors in the complicated mechanism of trade credit development in developing economies are unknown. Further research using firm-level micro data is needed to investigate in more detail what factors promote the development of trade credit in developing economies, including China. 


\section{References}

Acemoglu, D, and Johnson, S (2005), 'Unbundling Institutions'. Journal of Political Economy, 113: 949-995.

Aktas, N, Bodt, E, Lobez, F, and Statnik C (2012), 'The information content of trade credit'. Journal of Banking and Finance 36: 1402-1413.

Arellano, M, and Bond, S (1991), 'Some tests of specifications for panel data: Monte Carlo evidence and an application to employment equations'. Review of Economic Studies 58: 277-297.

Allen, F, Qian, J, and Qian, M (2005), 'Law, finance, and economic growth in China'. Journal of Financial Economics 77: 57-116.

Ayyagari, M, Demirgüc-Kunt, A, and Maksimovic, V (2010), 'Formal versus informal finance: Evidence from China'. Review of Financial Studies 23: 3048-3097.

Biais, B, and Gollier, C (1997), 'Trade Credit and Credit Rationing'. Review of Financial Studies 10: 903-937.

Blundell, R, and Bond, S (1998), 'Initial conditions and moment restriction in dynamic panel data models'. Journal of Econometrics 87: 115-144.

Brandt, L, and Li, H (2003), 'Bank discrimination in transition economies: Ideology, Information, or Incentives?' Journal of Comparative Economics 31: 387-413.

Boyreau-Debray, G, (2003), 'Financial intermediation and growth: Chinese style'. Policy Research Working Paper No. 3027, World Bank.

Burkart, M, and Ellingsen, T (2004), 'In-kind finance: A theory of trade credit'. American Economic Review 94: 569-590.

Cai, H, Fang, H, and Xu, L (2011), 'Eat, drink, firms, government: An investigation of corruption from the entertainment and travel costs of Chinese firms'. Journal of Law and Economics 54: 55-78.

Cheng, X, and Degryse, H (2007), 'The impact of banks and non-bank financial institutions on local economic growth in China'. BOFIT Discussion Papers 22/2007, Bank of Finland.

Cull, R, and Xu, L (2005), 'Institutions, ownership, and finance: the Determinants of profit reinvestment among Chinese Firms'. Journal of Financial Economics, 77: 117-146.

Cull, R, Xu, L, and Zhu, T (2009), 'Formal finance and trade credit during China's transition'. Journal of Financial Intermediation 18: 173-192.

Demirgüc-Kunt, A, and Maksimovic, V (2001), 'Firms as financial intermediaries: Evidence from trade credit data'. World Bank Policy Research Working Paper 2696, World Bank. 
Ding, S, Guariglia, A, and Knight, J (2012), 'Investment and financing constraint in China: Does working capital make a difference?'. Journal of Banking and Finance 37: 1490-1507.

Du, J, Lu, Y, and Tao, Z (2012), 'Bank loans vs. trade credit: Evidence from China'. Economics of Transition 20: 1-24.

Fabbri, D, and Klapper, L (2008), 'Market power and the matching of trade credit terms'. World Bank Policy Research Working Paper 4754, World Bank.

Fafchamps, M (2004), Market Institutions in Sub-Saharan Africa: Theory and Evidence. MIT Press, Cambridge (Massachusetts)/London.

Fisman, R, and Love, I (2003) 'Trade Credit, Financial Intermediary Development, and Industry Growth'. The Journal of Finance 58: 353-374.

Fisman, R, and Raturi, M (2004), 'Does competition encourage credit provision? Evidence from African trade credit relationships'. Review of Economics and Statistics 86: 345-352.

Giannetti, M, Burkart, M, and Ellingsen, T (2011), 'What You Sell Is What You Lend? Explaining Trade Credit Contracts'. Review of Financial Studies 24: 1299-1335.

Guariglia, A, Liu, X, and Song, L (2011), 'Internal finance and growth: Microeconometric evidence on Chinese firms'. Journal of Development Economics 96: 79-84.

Guariglia, A, and Poncet, S (2008), 'Could financial distortion be no impediment to economic growth after all? Evidence from China'. Journal of Comparative Economics 36: 633-657.

Ge, Y, and Qiu, J (2007), 'Financial development, bank discrimination and trade credit'. Journal of Banking and Finance 31: 513-530.

Hyndman, K, and Serio, G (2010), 'Competition and inter-firm credit: Theory and evidence from firm-level data in Indonesia'. Journal of Development Economics 93: 88-108.

Johnson, S, McMillan, J, and Woodruff, C (2002), 'Court and relational contracts'. Journal of Law, Economics, and Organization 18: 221-277.

Nilsen, H (2002), 'Trade Credit and The Bank Lending Channel of Monetary Transmission'. Journal of Money, Credit, and Banking 34: 226-253.

Özlü, P, and Yalçın, C. (2012), 'The trade credit channel of monetary policy transmission: Evidence from Non-Financial Firms in Turkey'. Emerging Markets Finance \& Trade 48: $102-117$.

Petersen, A, and Rajan, G (1997), 'Trade Credit: Theories and Evidence'. Review of Financial Studies 10: 661-691.

Roodman, D (2008), 'How to do xtabond2: An introduction to difference and system GMM 
in Stata'. Working Paper 103, Center for Global Development.

Roodman, D (2009), 'A note on the theme of too many instruments'. Oxford Bulletin of Economics and Statistics 71: 135-158.

Van Horen, N (2004), 'Trade credit as a competitiveness tool; Evidence from developing countries'. MPRA Paper 2792.

Windmeijer, F (2005), 'A finite sample correction for the variance of linear two-step GMM estimators'. Journal of Econometrics 126: 25-51. 


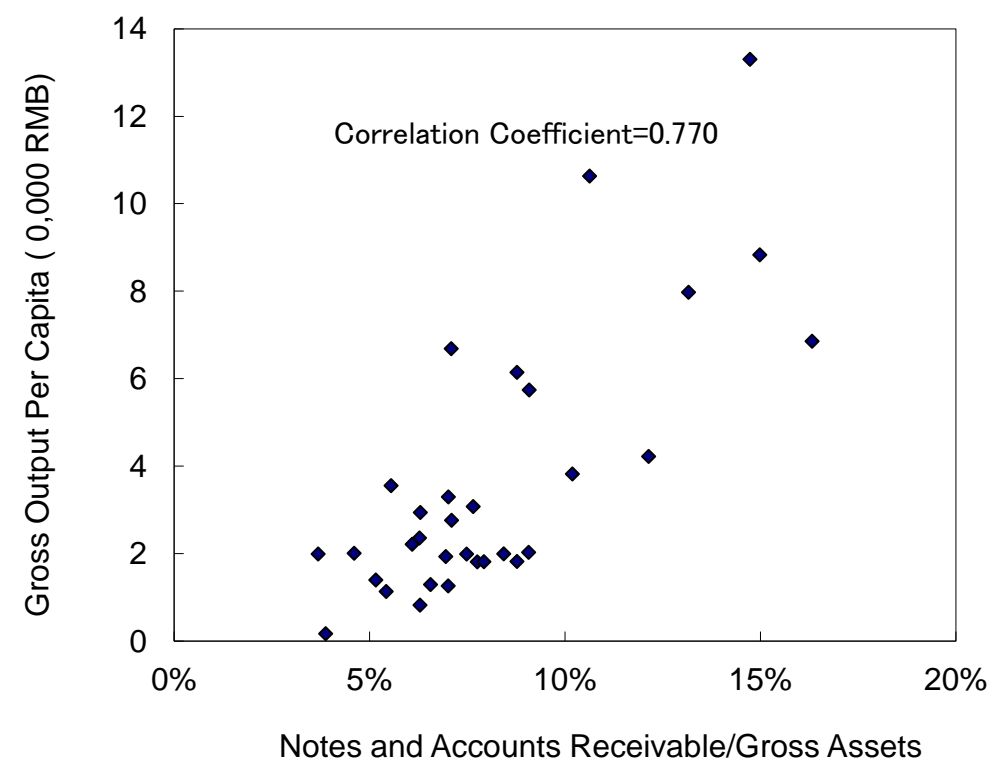

Fig. 1 Correlation between notes and accounts receivable/gross assets and gross output per capita in provinces for all industrial firms in 2008

Source: China Economic Census Yearbook 2008 (zhonggou jingji pucha nianjian)

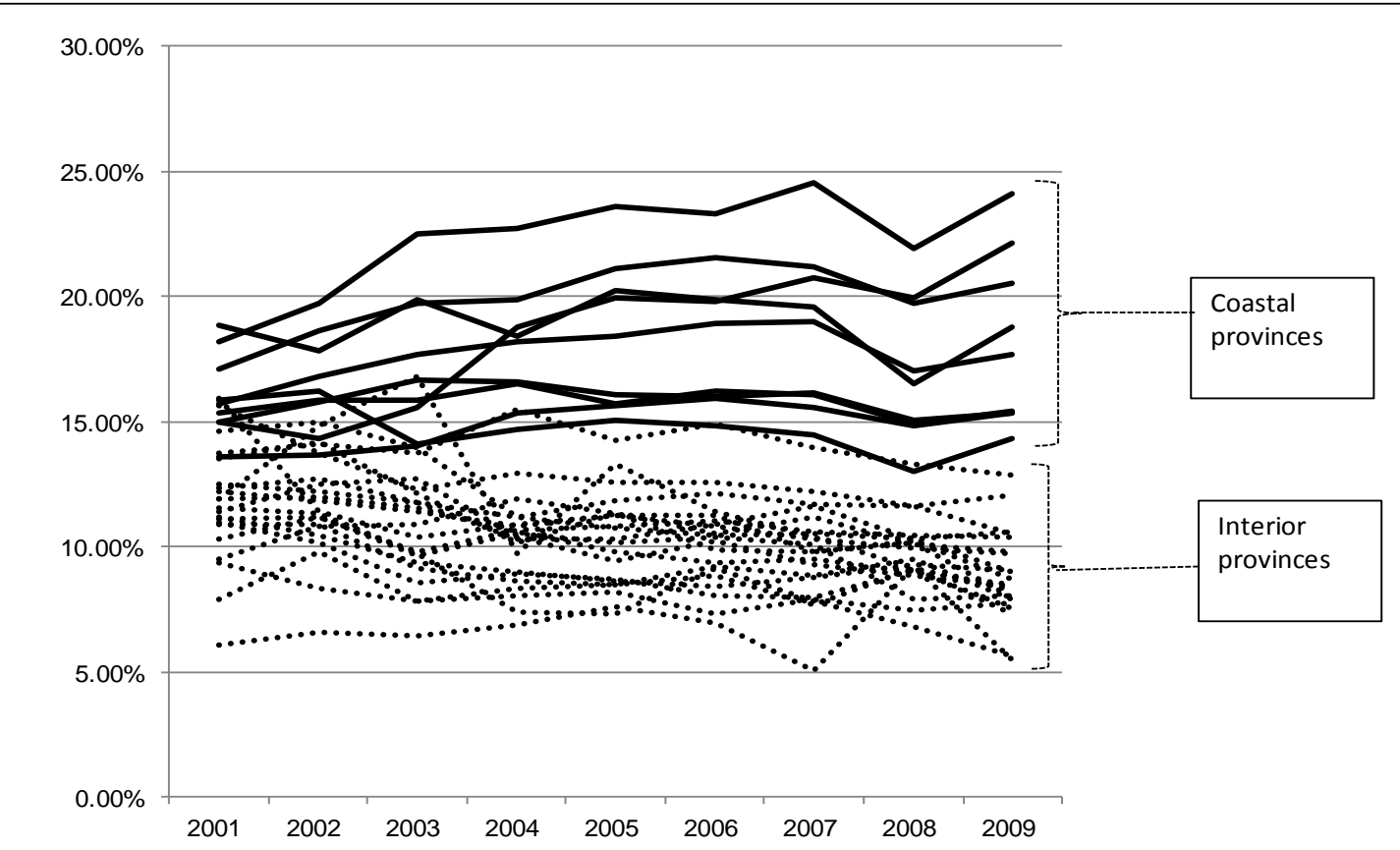

Fig. 2 Accounts receivable/gross assets in time series for non-state holding industrial firms

Source: China Indusry Economy Statistical Yearbook (zhonggou gongye jingji tongji nianjian ), various years, and China Economic Census Yearbook (zhonggou jingji pucha)

1 The coastal areas here comprise the following provinces: Beijing, Tianjin, Hebei, Liaoning, Shanghai, Jiangsu, Zhejiang, Shandong, Fujian, and Guangdong. The interior areas studied comprise the other provinces. 
Table 1

Descriptive Statistic for 31 Provinces during the Period 2001-2009

\begin{tabular}{|c|c|c|c|}
\hline Accounts receivable & Mean & Std. Dev. & Obs. No. \\
\hline \multicolumn{4}{|l|}{ Dependent Variables: Private Sector Investment } \\
\hline Accounts receivable for non state-sector firms / gross assets & 0.124 & 0.040 & 279 \\
\hline \multicolumn{4}{|l|}{ Independent Variables } \\
\hline \multicolumn{4}{|l|}{ (1) Competitive market environment } \\
\hline $\begin{array}{l}\text { (Number of firms / province industrial gross output })_{-1} \\
\text { (per } 100 \text { millions RMB) }\end{array}$ & 1.469 & 1.945 & 279 \\
\hline Producer price indices for manufactured goods ${ }_{-1}^{1}$ & 0.946 & 0.147 & 279 \\
\hline Presence of SMEs in gross output ${ }_{-1}$ & 0.633 & 0.279 & 279 \\
\hline \multicolumn{4}{|l|}{ (2) Legal system } \\
\hline$(\text { Patent applications accepted / province GRP })_{-1}$ & 1.395 & 0.993 & 279 \\
\hline $\begin{array}{l}\text { (Number of commercial cases received by the court / province } \\
\text { population })_{-1}\end{array}$ & 1.711 & 0.795 & 279 \\
\hline$(\text { Number of lawyers / province population })_{-1}$ & 1.399 & 1.423 & 279 \\
\hline \multicolumn{4}{|l|}{ (3) Corruption } \\
\hline$(\text { Number of registered corruption cases / province population })_{-1}$ & 3.012 & 1.007 & 279 \\
\hline \multicolumn{4}{|l|}{ (4) Financial factors } \\
\hline (Bank loans for non-state-sector firms / gross assets $)_{-1}$ & 0.482 & 0.089 & 279 \\
\hline Share of non-state-owned commercial banks in total bank lending. & 0.461 & 0.113 & 279 \\
\hline
\end{tabular}

${ }^{1}$ The Producer price indices for manufactured goods ${ }_{-1}$ used in our regression is deflated one by GDP deflator for each year. 
Dep. Var. $=$ Accounts receivable for non state-sector firms / gross assets

Independent Variables

\section{Province dummy variable}

Year dummy variables

(1) Competitive market environment

(Number of firms / province industrial gross output $)_{-1}$

Producer price indices for manufactured goods

Presence of SMEs in gross output

(2) Legal system

(Patent applications accepted / province GRP $)_{-1}$

(Number of commercial cases received by the court / province population )

(Number of lawyers / province population $)_{-1}$

(Number of commercial cases received by the court / province population $)_{-}$

$\times(\text { Number of lawyers / province population })_{-1}$

(3) Corruption

(Number of registered corruption cases / province population $)_{-1}$

\section{$-0.005^{*}$}

$-0.006^{*}$

$(-2.272)$

$(-2.489)$

$-0.006^{*}$

$(-2.162)$

$-0.005^{* *}$

$-0.007$

$(-2.655)$

$(-1.953)$

$(-2.009)$

$0.001 * *$

(2.610)

$\times$ (Number of lawyers / province population $)_{-1}$

(4) Financial factors

Share of non-state-owned commercial banks in total bank lending

(5) Lagged dependent variable

(Accounts receivable for non state-sector firms / gross assets $)_{-1}$

\begin{tabular}{lcccccc}
$0.021^{*}$ & $0.018^{*}$ & $0.020^{* *}$ & $0.027^{*}$ & $0.019^{*}$ & $0.029^{* *}$ & $0.026^{*}$ \\
$(2.076)$ & $(2.392)$ & $(2.611)$ & $(2.535)$ & $(2.302)$ & $(2.665)$ & $(2.372)$ \\
0.007 & 0.010 & 0.008 & $0.010^{*}$ & 0.008 & $0.008^{*}$ & 0.007 \\
$1.500)$ & $(1.695)$ & $(1.754)$ & $(2.355)$ & $(1.878)$ & $(1.969)$ & $(1.837)$ \\
& & & & & & \\
& & & & $-0.107^{*}$ & & $-0.086^{*}$ \\
& & & & $(-2.356)$ & & $(-2.048)$ \\
0.261 & 0.208 & 0.275 & 0.315 & 0.153 & 0.218 & 0.182 \\
0.198 & 0.266 & 0.132 & 0.180 & 0.400 & 0.196 & 0.300 \\
279 & 279 & 279 & 279 & 279 & 279 & 279 \\
\hline
\end{tabular}

$p$-value of Hansen test

279

279

279

${ }^{1}$ The table presents Blundel and Bond's two-step system GMM results. The dependent variable is Accounts receivable for non state-sector firms/gross assets.

We report in parentheses the $\mathrm{z}$ statistics that based on the Windmeijer (2005)'s finite sample correction to

the standard errors in two-step estimation.

${ }^{2}$ The table presents regression coefficients. Numbers in parentheses are the $\mathrm{z}$ statistics.

* Siginificant at $5 \%$.

** Siginificant at $1 \%$ 
Table 3

The First-stage Results for System GMM Estimation (1): Dep. Var = First-Differenced One ${ }^{1}$

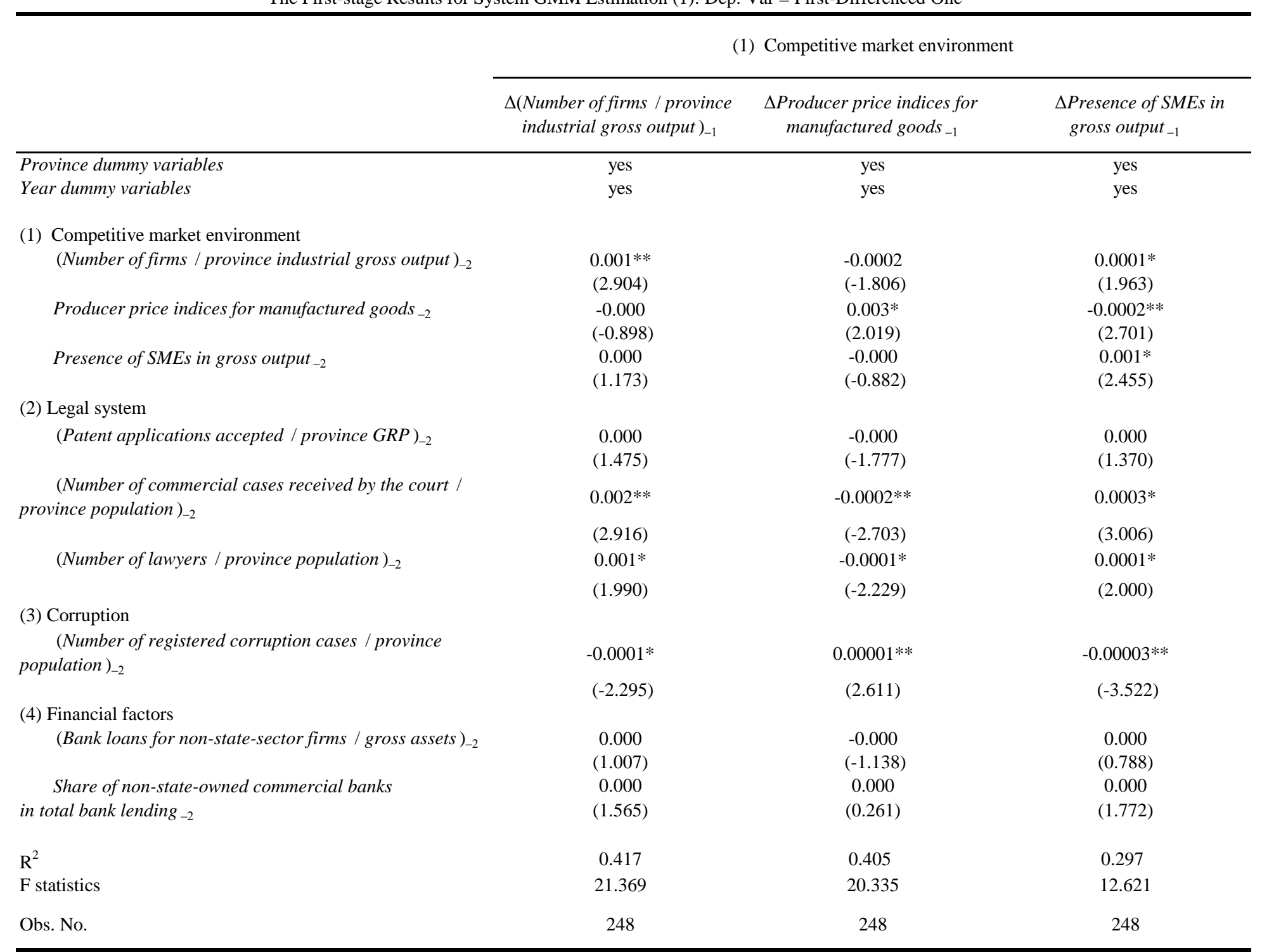

${ }^{1} \Delta x_{-1}$ is defined as change of variable $x$ between periods $\mathrm{t}-1$ and $\mathrm{t}-2$ :

$: x_{-1}-x_{-2}$. 
Table 4

The First-stage Results for System GMM Estimation (1): Dep. Var $=$ Level One $^{1}$

\begin{tabular}{|c|c|c|c|}
\hline & \multicolumn{3}{|c|}{ (1) Competitive market environment } \\
\hline & $\begin{array}{l}\text { (Number of firms / province } \\
\text { industrial gross output })_{-1}\end{array}$ & $\begin{array}{l}\text { Producer price indices for } \\
\text { manufactured goods } \\
-1\end{array}$ & $\begin{array}{l}\text { Presence of SMEs in gross } \\
\text { output }_{-1}\end{array}$ \\
\hline$\Delta$ Year dummy variables & yes & yes & yes \\
\hline \multicolumn{4}{|l|}{ (1) Competitive market environment } \\
\hline$\Delta(\text { Number of firms / province industrial gross output })_{-1}$ & $\begin{array}{l}0.010^{*} \\
(2.431)\end{array}$ & $\begin{array}{l}-0.002 * \\
(-2.021)\end{array}$ & $\begin{array}{l}0.035^{*} \\
(2.515)\end{array}$ \\
\hline$\Delta$ Producer price indices for manufactured goods $s_{-1}$ & $\begin{array}{l}-0.000 \\
(-1.025)\end{array}$ & $\begin{array}{c}0.029 * * \\
(2.890)\end{array}$ & $\begin{array}{l}-0.003 \\
(-0.894)\end{array}$ \\
\hline$\Delta$ Presence of SMEs in gross output ${ }_{-1}$ & $\begin{array}{l}0.006^{* *} \\
(2.774)\end{array}$ & $\begin{array}{l}-0.005 \\
(-0.732)\end{array}$ & $\begin{array}{l}0.018 * * \\
(2.737)\end{array}$ \\
\hline \multicolumn{4}{|l|}{ (2) Legal system } \\
\hline$\Delta(\text { Patent applications accepted / province GRP })_{-1}$ & $\begin{array}{l}0.006^{*} \\
(1.968)\end{array}$ & $\begin{array}{l}-0.001 \\
(-1.580)\end{array}$ & $\begin{array}{l}0.021^{*} \\
(2.130)\end{array}$ \\
\hline $\begin{array}{l}\Delta(\text { Number of commercial cases received by the court / } \\
\text { province population })_{-1}\end{array}$ & $0.028^{*}$ & $-0.002 *$ & $0.095^{* *}$ \\
\hline & $(2.331)$ & $(-2.489)$ & $(2.676)$ \\
\hline$\Delta(\text { Number of lawyers / province population })_{-1}$ & $0.010^{*}$ & $-0.001 * *$ & $0.033^{*}$ \\
\hline & $(1.965)$ & $(-3.047)$ & $(2.096)$ \\
\hline \multicolumn{4}{|l|}{ (3) Corruption } \\
\hline $\begin{array}{l}\Delta(\text { Number of registered corruption cases / province } \\
\text { population })_{-1}\end{array}$ & $-0.001 *$ & $0.0001 * *$ & -0.003 \\
\hline & $(-2.083)$ & $(2.727)$ & $(-1.925)$ \\
\hline \multicolumn{4}{|l|}{ (4) Financial factors } \\
\hline$\Delta(\text { Bank loans for non-state-sector firms / gross assets })_{-1}$ & $\begin{array}{c}0.001 \\
(0.914)\end{array}$ & $\begin{array}{l}-0.001 \\
(-1.155)\end{array}$ & $\begin{array}{c}0.004 \\
(0.785)\end{array}$ \\
\hline$\Delta$ Share of non-state-owned commercial banks & 0.001 & -0.000 & $0.003^{*}$ \\
\hline in total bank lending $_{-1}$ & $(1.189)$ & $(-1.574)$ & $(2.200)$ \\
\hline $\mathrm{R}^{2}$ & 0.381 & 0.361 & 0.260 \\
\hline F statistics & 18.388 & 16.878 & 10.497 \\
\hline Obs. No. & 248 & 248 & 248 \\
\hline
\end{tabular}

\footnotetext{
${ }^{1} \Delta x_{-1}$ is defined as change of variable $x$ between periods $\mathrm{t}-1$ and $\mathrm{t}-2$
}

$: x_{-1}-x_{-2}$. 
Table 5

The First-stage Results for System GMM Estimation (2): Dep. Var $=$ First-Differenced One ${ }^{1}$

\begin{tabular}{|c|c|c|c|}
\hline & \multicolumn{3}{|c|}{ (2) Legal system } \\
\hline & $\begin{array}{c}\Delta(\text { Patent applications accepted } \\
\text { / province GRP })_{-1}\end{array}$ & $\begin{array}{c}\Delta(\text { Number of commercial cases } \\
\text { received by the court / province } \\
\text { population })_{-1}\end{array}$ & $\begin{array}{l}\Delta(\text { Number of lawyers / } \\
\text { province population })_{-1}\end{array}$ \\
\hline Province dummy variables & yes & yes & yes \\
\hline Year dummy variables & yes & yes & yes \\
\hline \multicolumn{4}{|l|}{ (1) Competitive market environment } \\
\hline (Number of firms / province industrial gross output $)_{-2}$ & $\begin{array}{c}0.000 \\
(0.393)\end{array}$ & $\begin{array}{c}0.000 \\
(0.301)\end{array}$ & $\begin{array}{l}0.000 \\
(0.136)\end{array}$ \\
\hline Producer price indices for manufactured goods $s_{-2}$ & $\begin{array}{l}-0.000 \\
(-0.048)\end{array}$ & $\begin{array}{l}-0.000 \\
(-0.013)\end{array}$ & $\begin{array}{l}-0.000 \\
(-0.085)\end{array}$ \\
\hline Presence of SMEs in gross output ${ }_{-2}$ & $\begin{array}{c}0.002 \\
(1.043)\end{array}$ & $\begin{array}{c}0.002 \\
(0.673)\end{array}$ & $\begin{array}{c}0.000 \\
(0.582)\end{array}$ \\
\hline \multicolumn{4}{|l|}{ (2) Legal system } \\
\hline (Patent applications accepted / province GRP $)_{-2}$ & $\begin{array}{l}0.002 * * \\
(3.895)\end{array}$ & $\begin{array}{l}0.001 * \\
(2.189)\end{array}$ & $\begin{array}{l}0.001 * \\
(1.965)\end{array}$ \\
\hline $\begin{array}{l}\text { (Number of commercial cases received by the court / } \\
\text { province population })_{-2}\end{array}$ & $0.0005 * *$ & $0.001 * *$ & $0.001^{*}$ \\
\hline \multirow{3}{*}{ (Number of lawyers / province population $)_{-2}$} & $(2.613)$ & (7.049) & $(2.524)$ \\
\hline & $0.0004 *$ & $0.001 * *$ & $0.0001 * *$ \\
\hline & $(2.028)$ & $(2.826)$ & $(3.868)$ \\
\hline \multicolumn{4}{|l|}{ (3) Corruption } \\
\hline $\begin{array}{l}\text { (Number of registered corruption cases / province } \\
\text { population })_{-2}\end{array}$ & 0.000 & 0.000 & 0.000 \\
\hline & $(0.291)$ & $(0.118)$ & $(0.010)$ \\
\hline \multicolumn{4}{|l|}{ (4) Financial factors } \\
\hline (Bank loans for non-state-sector firms / gross assets $)_{-2}$ & $\begin{array}{c}0.000 \\
(1.201)\end{array}$ & $\begin{array}{c}0.000 \\
(0.706)\end{array}$ & $\begin{array}{c}0.000 \\
(0.670)\end{array}$ \\
\hline Share of non-state-owned commercial banks & 0.000 & 0.000 & 0.000 \\
\hline in total bank lending $_{-2}$ & $(0.525)$ & $(0.049)$ & $(0.210)$ \\
\hline $\mathrm{R}^{2}$ & 0.357 & 0.349 & 0.288 \\
\hline F statistics & 16.587 & 16.016 & 12.084 \\
\hline Obs. No. & 248 & 248 & 248 \\
\hline
\end{tabular}

${ }^{1} \Delta x_{-1}$ is defined as change of variable $x$ between periods $\mathrm{t}-1$ and $\mathrm{t}-2$

$: x_{-1}-x_{-2}$. 
Table 6

The First-stage Results for System GMM Estimation (2): Dep. Var $=$ Level One $^{1}$

(2) Legal system

\begin{tabular}{ccc}
\cline { 2 - 3 } & $\begin{array}{c}\text { (Number of commercial cases } \\
\text { received by the court / } \\
\text { province population })_{-1}\end{array}$ & $\begin{array}{c}\text { (Number of lawyers / province } \\
\text { population })_{-1}\end{array}$ \\
\hline
\end{tabular}

$\Delta$ Year dummy variables

yes

0.001

Competitive market environment

$\Delta$ (Number of firms / province industrial gross output $)_{-}$

$\Delta$ Producer price indices for manufactured goods $s_{-1}$

$\triangle$ Presence of SMEs in gross output ${ }_{-1}$

(2) Legal system

$\Delta(\text { Patent applications accepted / province GRP })_{-1}$

$\Delta$ (Number of commercial cases received by the court I province population $)_{-1}$

$\Delta(\text { Number of lawyers / province population })_{-1}$

(3) Corruption

$\Delta$ (Number of registered corruption cases / province population $)_{-1}$

(4) Financial factors

$\Delta(\text { Bank loans for non-state-sector firms / gross assets })_{-1}$

$\Delta$ Share of non-state-owned commercial banks in total bank lending

$\mathrm{R}^{2}$

F statistics

Obs. No.

$\begin{array}{ccc}0.001 & 0.000 & 0.000 \\ (1.028) & (0.597) & (0.706) \\ 0.000 & -0.001 & -0.001 \\ (0.444) & (-1.099) & (-0.968) \\ 0.017 & 0.025 & 0.017 \\ (0.630) & (1.001) & (0.588) \\ & & \\ 0.026^{* *} & 0.011^{* *} & 0.011^{* *} \\ (3.598) & (2.618) & (2.883) \\ 0.005^{*} & 0.014^{* *} & 0.012 \\ (2.455) & (4.858) & (1.756) \\ 0.005^{*} & 0.010^{*} & 0.001 * * \\ (2.117) & (2.127) & (4.458) \\ & & \\ 0.003 & 0.001 & 0.005 \\ (0.158) & (0.047) & (0.434) \\ & & \\ 0.018 & 0.009 & 0.012 \\ (0.132) & (0.086) & 0.182) \\ 0.010 & 0.006 & (0.510) \\ (0.342) & (0.199) & 0.247 \\ 0.285 & & 9.800 \\ 11.908 & 0.325 & 248 \\ 248 & 14.384 & \end{array}$

yes

.706)

0.968

0.017

$(2.883)$

0.012

$(1.756)$

(4.458)

0.005

.012

(182)

0.247

248

${ }^{1} \Delta x_{-1}$ is defined as change of variable $x$ between periods $\mathrm{t}-1$ and $\mathrm{t}-2$

$: x_{-1}-x_{-2}$. 
Table 7

The First-stage Results for System GMM Estimation (3) and (4): Dep. Vars = First-Differenced Ones ${ }^{1}$

\begin{tabular}{|c|c|c|}
\hline & (3) Corruption & (4) Financ \\
\hline & $\begin{array}{c}(\text { Number of registered } \\
\text { corruption cases / province } \\
\text { population })_{-1}\end{array}$ & $\begin{array}{l}\Delta(\text { Bank loans for non-state- } \\
\text { sector firms / gross assets })_{-1}\end{array}$ \\
\hline Province dummy variables & yes & yes \\
\hline Year dummy variables & yes & yes \\
\hline \multicolumn{3}{|l|}{ (1) Competitive market environment } \\
\hline (Number of firms / province industrial gross output $)_{-2}$ & $\begin{array}{l}-0.000 \\
(-0.495)\end{array}$ & $\begin{array}{c}0.000 \\
(0.809)\end{array}$ \\
\hline Producer price indices for manufactured goods $s_{-2}$ & $\begin{array}{l}-0.000 \\
(-0.691)\end{array}$ & $\begin{array}{c}0.000 \\
(1.297)\end{array}$ \\
\hline Presence of SMEs in gross output $t_{-2}$ & $\begin{array}{l}-0.000 \\
(-0.631)\end{array}$ & $\begin{array}{l}-0.000 \\
(-0.739)\end{array}$ \\
\hline \multicolumn{3}{|l|}{ (2) Legal system } \\
\hline (Patent applications accepted / province GRP $)_{-2}$ & $\begin{array}{l}-0.001 * \\
(-2.192)\end{array}$ & $\begin{array}{c}0.000 \\
(1.762)\end{array}$ \\
\hline \multirow[t]{2}{*}{$\begin{array}{l}\text { (Number of commercial cases received by the court / } \\
\text { province population })_{-2}\end{array}$} & $-0.003^{*}$ & 0.000 \\
\hline & $(-2.499)$ & $(1.250)$ \\
\hline \multirow[t]{2}{*}{$(\text { Number of lawyers / province population })_{-2}$} & $-0.001 * *$ & 0.000 \\
\hline & $(-7.175)$ & $(1.410)$ \\
\hline \multicolumn{3}{|l|}{ (3) Corruption } \\
\hline \multirow[t]{2}{*}{$\begin{array}{l}\text { (Number of registered corruption cases / province } \\
\text { population })_{-2}\end{array}$} & $0.002 * *$ & -0.000 \\
\hline & $(10.482)$ & $(-1.406)$ \\
\hline \multicolumn{3}{|l|}{ (4) Financial factors } \\
\hline (Bank loans for non-state-sector firms / gross assets $)_{-2}$ & $\begin{array}{c}-0.0005^{* *} \\
(-3.001)\end{array}$ & $\begin{array}{l}0.011 * * \\
(13.930)\end{array}$ \\
\hline Share of non-state-owned commercial banks & $-0.001^{*}$ & $0.005^{* *}$ \\
\hline in total bank lending $_{-2}$ & $(-2.523)$ & $(4.020)$ \\
\hline $\mathrm{R}^{2}$ & 0.395 & 0.279 \\
\hline F statistics & 19.505 & 11.561 \\
\hline Obs. No. & 248 & 248 \\
\hline
\end{tabular}

${ }^{1} \Delta x_{-1}$ is defined as change of variable $x$ between periods $\mathrm{t}-1$ and $\mathrm{t}-2$ :

$: x_{-1}-x_{-2}$. 
Table 8

The First-stage Results for System GMM Estimation (3) and (4): Dep. Vars = Level Ones ${ }^{1}$

\begin{tabular}{|c|c|c|}
\hline & (3) Corruption & (4) Financ \\
\hline & $\begin{array}{c}\text { (Number of registered } \\
\text { corruption cases / province } \\
\text { population })_{-1} \\
\end{array}$ & $\begin{array}{l}\text { (Bank loans for non-state- } \\
\text { sector firms / gross assets })_{-1}\end{array}$ \\
\hline$\Delta$ Year dummy variables & yes & yes \\
\hline \multicolumn{3}{|l|}{ (1) Competitive market environment } \\
\hline$\Delta(\text { Number of firms / province industrial gross output })_{-1}$ & $\begin{array}{c}0.000 \\
(0.493)\end{array}$ & $\begin{array}{c}0.000 \\
(1.157)\end{array}$ \\
\hline$\Delta$ Producer price indices for manufactured goods $s_{-1}$ & $\begin{array}{c}0.000 \\
(0.086)\end{array}$ & $\begin{array}{l}-0.000 \\
(-1.640)\end{array}$ \\
\hline$\Delta$ Presence of SMEs in gross output ${ }_{-1}$ & $\begin{array}{c}0.000 \\
(0.844)\end{array}$ & $\begin{array}{c}0.001 \\
(1.449)\end{array}$ \\
\hline \multicolumn{3}{|l|}{ (2) Legal system } \\
\hline$\Delta(\text { Patent applications accepted / province GRP })_{-1}$ & $\begin{array}{l}-0.006 \\
(-1.801)\end{array}$ & $\begin{array}{c}0.001 \\
(0.901)\end{array}$ \\
\hline $\begin{array}{l}\Delta(\text { Number of commercial cases received by the court / } \\
\text { province population })_{-1}\end{array}$ & $-0.044 * *$ & 0.000 \\
\hline & $(-7.749)$ & $(0.936)$ \\
\hline$\Delta(\text { Number of lawyers / province population })_{-1}$ & $-0.012 * *$ & 0.001 \\
\hline & $(-3.226)$ & $(1.132)$ \\
\hline \multicolumn{3}{|l|}{ (3) Corruption } \\
\hline $\begin{array}{l}\Delta(\text { Number of registered corruption cases / province } \\
\text { population })_{-1}\end{array}$ & $0.019 * *$ & -0.001 \\
\hline & $(10.399)$ & $(-1.325)$ \\
\hline \multicolumn{3}{|l|}{ (4) Financial factors } \\
\hline$\Delta(\text { Bank loans for non-state-sector firms / gross assets })_{-}$ & $\begin{array}{r}-0.005 * * \\
(-2.578)\end{array}$ & $\begin{array}{l}0.137 * * \\
(14.767)\end{array}$ \\
\hline $\begin{array}{l}\Delta \text { Share of non-state-owned commercial banks } \\
\text { in total bank lending }\end{array}$ & $\begin{array}{r}-0.004 * * \\
(-2.877)\end{array}$ & $\begin{array}{l}0.059 * * \\
(5.609)\end{array}$ \\
\hline $\mathrm{R}^{2}$ & 0.383 & 0.251 \\
\hline F statistics & 18.545 & 10.012 \\
\hline Obs. No. & 248 & 248 \\
\hline
\end{tabular}

${ }^{1} \Delta x_{-1}$ is defined as change of variable $x$ between periods $\mathrm{t}-1$ and $\mathrm{t}-2$ :

$: x_{-1}-x_{-2}$. 